\title{
Risk Analysis of Islamic State (IS) Network Development in Southeast Asia Based on 3D Matrix
}

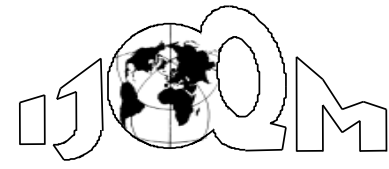

DOI: $10.46970 / 2020.26 .3 .3$

Volume 26, Number 3

September 2020, pp. 195-223
Amarulla Octavian

Joni Widjayanto

I Nengah Putra

Indonesia Defense University

(amarulla.octavian@idu.ac.id)

(joni.widjayanto@idu.ac.id)

(nengah.putra@idu.ac.id)

A. Kukuh Susilo

Okol S. Suharyo

Indonesia Naval Technology College

(akukuhsusilo@sttal.ac.id)

(okolsrisuharyo@sttal.ac.id)

The threat of terror in Southeast Asia has been currently divided into three generations of terror: Al-Qaeda terror network, ISIS terror network and IS terror network.This study aims at providing a risk analysis on the development of the Islamic State network in Southeast Asia. This study employed Analytical Hierarchy Process (AHP) approach, TOPSIS. The AHP method is used to give weight to risk identification criteria. The TOPSIS method is used to provide the value analysis of threats, vulnerability, and impact in order to determine the threat-based risk level assessment, vulnerability, and the impact of the TOPSIS calculation results. The risk analysis of the development of Islamic State in Southeast Asia resulted three countries were categorized in the category of Low: Indonesia, Malaysia and Thailand. Indonesia has the value of risk factor of 0.170; Malaysia has the value of risk factor of 0.088 and Thailand has the value of risk factor of 0.176. On the other hand, the Philippines has the value of risk factor of 0.351 in the category of Guarded.

Keywords: Maritime Risk Analysis, Network, Islamic State, Analytical Hierarchy Process (AHP), Technique for Order Preference by Similarity to Ideal Solution (TOPSIS), ASEAN

\section{Introduction}

The establishment of Association of Southeast Asian Nations (ASEAN) as an international organization in Southeast Asia on August 8, 1967 in Bangkok with aimed at creating ASEAN countries that are peaceful, safe, stable and prosperous (Purwendah, 2018). However, current almost all Southeast Asian countries suffer terrorist threats, such as Islamic territorialism and anarchic activities of international terror networks. The anarchic activities include Al-Qaeda of Bali bombing 1 in Indonesia, Islamic State of Iraq and Syria (ISIS) in Syria, and Islamic State (IS) of Moro Islamic Liberation Front in the Philippines (Fitriani, et al., 2018).

The threat of terror in Southeast Asia has been currently divided into three generations of terror: Al-Qaeda terror network, ISIS terror network and IS terror 
network. These three threats are challenging national development as well as the fundamentals of social, national, and political life of people in Southeast Asia (Nahdohdin, et al., 2019). The terror networks varied from Jemaah Islamiyah (JI), Mujahiddin, to Katibah Nusantara are now increasingly growing stronger and more fertile due to economic, politic, and leadership crisis caused by the China-United States trade war. The United Nations has declared "Global War on Terror". ASEAN also formed Ministerial Meeting on Transnational Crime (AMMTC) aiming at preventing transnational crimes including acts of terrorism (Aslam, 2009). Based on these problems, this study aims at providing a risk analysis on the development of the Islamic State network in Southeast Asia. This study employed Analytical Hierarchy Process (AHP) approach, TOPSIS. The AHP method is used to give weight to risk identification criteria. The TOPSIS method is used to provide the value analysis of threats, vulnerability, and impact in order to determine the threatbased risk level assessment, vulnerability, and the impact of the TOPSIS calculation results.

This study was urged by the development of the threat of Islamic States (IS) in Southeast Asia countries such as Thailand, Malaysia, the Philippines and Indonesia. ASEAN cooperation in dealing with the returnees of Islamic State of Iraq and Syria (ISIS). The returnees return to their countries to become a lone wolf. This research is limited to four major countries in Southeast Asia: Indonesia, Malaysia, Thailand, and the Philippines. This study is expected to contribute to the development of defense science and technology in the field of Asymmetric warfare. Furthermore, this research is expected to be used as a consideration and input for stakeholders in ASEAN cooperation and terrorism threat prevention.

There previous studies supporting this research. First, Analysis of National Maritime Security Strategy as an Effect of Regional Development using SWOT, Fuzzy Multi Criteria Decision Making (FMCDM) and Borda (Susilo, Putra, Ahmadi, \& Suharyo, 2019). Risk Evaluation Of Terrorist Attacks Against Important Chemical Industries In Urban Areas (Yang, 2019). Data Analysis Method Of Terrorist Attacks Based On AHP-DBSCAN Method (Wang, et al., 2019). A Decision Framework For Managing The Risk Of Terrorist Threats At Rail Stations Interconnected With Airports (Kaewunruen, et al., 2018). On The Risk Assessment Of Terrorist Attacks Coupled With Multi-Source Factors (Zhang, et al., 2018). Risk Assessment And The Prevention Of Radicalization From Nonviolence Into Terrorism (Sarma, 2017). Adversarial Risk Analysis in support of defensive resource allocation for counterterrorism (Zawadzki, et al., 2017). Rationality Of Terrorist Acts, Counterterrorism And Risk Analysis (Pavlićević, 2017). Risk Reduction In Terrorism Cases: Sentencing And The Post-Conviction Environment (Berkell, 2017). Previous studies related to AHP and TOPSIS are AHP-TOPSIS Model to Evaluate Maintenance Strategy using RAMS and Production Parameters (Bona \& Falcone, 2019). Implementing Fuzzy TOPSIS on Project Risk Variable Ranking (Husin, et al., 2019). Risk Assessment Using Fuzzy TOPSIS and PRAT for Sustainable Engineering Projects (Koulinas, et al., 2019). Risk Management In Urban Tunnels Using Methods Of Game Theory And Multi-Criteria Decision-Making (Nikkhah, et al., 2019). A Hybrid Fuzzy TOPSIS - Best Worst Method for Risk Prioritization in Megaprojects (Norouzi \& Namin, 2019). Improved AHP-TOPSIS Model for The Comprehensive Risk Evaluation of Oil And Gas Pipelines (Wang \& Duan, 2019). 
Risk Level Evaluation on Construction Project Lifecycle Using Fuzzy Comprehensive Evaluation and TOPSIS (Gebrehiwet \& Luo, 2019). Implementation of AHP and TOPSIS Method to Determine the Priority of Improving the Management of Government's Assets (Febriansyah, et al., 2017). Risk Management and Control of Dams Based on Integrating TOPSIS and RAM-D Techniques (Case Study: Paveh Rood Dam, Iran) (Sadeh \& Rezaian, 2017). Project Risk Assessment in Enterprises with the Use of TOPSIS Method in the 2014-2020 Perspective (Walaszczyk, 2016). Using Fuzzy AHP And Fuzzy TOPSIS Approaches For Assessing Safety Conditions At Worksites In Construction Industry (Basahel \& Taylan, 2016). Group Decision-Making Using Improved Multi-Criteria Decision Making Methods for Credit Risk Analysis (Wua, et al., 2016). Urban Network Risk Assessment Based on Data Fusion Concept using Fuzzy-AHP, TOPSIS and VIKOR in GIS Environment (Rokhsari \& Sadeghi-Niaraki, 2015). A fuzzy AHP-TOPSIS Framework for The Risk Assessment of Green Supply Chain Implementation In The Textile Industry (Nazam, et al., 2015).

The exploration in this study is divided into some sections. Section 2 describes the Islamic State, ASEAN countries, and the risk analysis method used. Section 3 explains Islamic state terrorism risk analysis in Southeast Asia. Section 4 discusses the value of risk analysis. Finally, Section 5 concludes the study.

\subsection{Terrorism}

\section{Material/Methodology}

Terror is a phenomenon that has quite a long life in history, this is evidenced from the root of the word terror "cimbricus terror" (Beinoravičius \& Vainiute, 2017). It was derived from Roman phrase which meant "to frighten" which describes the panic that occurred when the opposing force battled fiercely and violently (Baker, 2014). Then this word was broadly used for the first time during the French Revolution as le terreur or terrere which was used when there was brutal violence by beheading many people who were accused of anti-government. Thus, terrorism could be interpreted as intimidation and brutal acts against civil society by certain reasons (Beinoravičius \& Vainiutè, 2017).

There is an expansion where the act of terrorism was once one of the methods of government to control the political situation to be crime against state and humanity (Filippo, 2008). Recently, the acts of terrorism also attack the conscience of individuals (crime against conscience) due to the random and erratic selection of attacks that cause public unrest. Terrorism today can be categorized as asymmetric warfare. Unlike traditional warfare where military power and resources are the main focus, asymmetric warfare prefers psychological pressure (Fitzpatrick, 2003).

\subsection{Indonesia}

Indonesia is the largest archipelago in the world. Indonesia consists of 17,499 islands in the area of sea water 5.8 million square kilometers. In other word, 2/3 of Indonesia's territory comprises of waters territory is sea. Indonesia has a long coastline of 81,900 square kilometers. Indonesia is made up of thousand islands and is bordered by 10 countries: Singapore, Malaysia, the Philippines, India, Vietnam, Thailand, Cambodia, the Republic of Palau, Papua New Guinea (PNG) and Australia. Most of the borders are separated by the sea (Susilo, et al., 2018). Only 
three of them are land border: Malaysia, Papua New Guinea (PNG) and Timor Leste. Administratively, Indonesia's borders are located in in 12 Provinces and 38 Regencies/ Cities. The 12 provinces are the province of Nangroe Aceh Darussalam (NAD), North Sumatra, Riau, Kepulauan Riau, West Kalimantan, East Kalimantan, North Sulawesi, Maluku, North Maluku, East Nusa Tenggara (NTT ), Papua and West Papua. The border area consists of land, sea and air border areas that are widely distributed with diverse typologies, ranging from the remote areas to small frontline islands and border villages (Malta, et al., 2018).

\subsection{Malaysia}

Malaysia declared its independence on 31 August 1957. Geographically, Malaysia is located in the Southeast Asian region. Malaysia has two main regions separated by the South China Sea into Peninsular Malaysia and East Malaysia. Astronomically, Malaysia is located near to the equator with coordinates of $2^{\circ} 30^{\prime} \mathrm{N} 112^{\circ} 30^{\prime} \mathrm{E}$. The total land area of Malaysia is 329,847 square kilometers comprising of land area of \pm 328,657 square kilometers and water area of $\pm 1,190$ square kilometers. Malaysia's total length of coastline is $\pm 4,675 \mathrm{~km}$, which are the coastline in Peninsular Malaysia of $\pm 2,068 \mathrm{~km}$ and East Malaysia $\pm 2,607 \mathrm{~km}$ (Aslam, 2009).

West and East Malaysia are separated by the South China Sea along the $+540 \mathrm{~km}$ in the Peninsular Malaysia of 131,805 square kilometers bordering with Thailand in the north and Singapore in the south. Meanwhile, Sabah and Sarawak regions cover an area of 73,997 square kilometers and 124,450 square kilometers respectively. Geographically, Malaysia has neighbour borders to other countries such as Indonesia by $1,782 \mathrm{~km}$, Thailand by $506 \mathrm{~km}$, and Brunei by $381 \mathrm{~km}$ totalling of $\pm 2,669 \mathrm{~km}$ (Hatta \& Ali, 2013).

\subsection{Thailand}

Thailand is located in Southeast Asia. Culturally, the religion, language and culture of Muangthai Muslim minority living in Patani (Southern Thailand) is Malay nation. Moreover, it geographically is bordered to Malaysia. The kingdom of Thailand is divided into 76 Provinces called Changwat. These provinces are grouped into 5 which then are divided into 795 districts called Amphoe. Then Amphoe is divided into 81 minor districts known as King Amphoe and 50 districts of Bangkok called Khet. Furthermore, both King Amphoe and Khet consist of 7,236 communities called Tambon. Tambon consists of 55,746 villages called Muban, 123 municipalities called Tesaban, and 729 Sanitary Districts called Sukhaphiban (Leepreecha, 2019).

\subsection{The Philippines}

The Republic of the Philippines is an island country of Southeast Asia. The capital city of the Philippines is Manila. The total area of the Philippines is $\pm 300,000$ square kilometers with land area of 298,170 square kilometers and water area of 1,830 square kilometers with 7,107 islands (Putra, et al., 2019). Luzon Island (in the north) and Mindanao Island (in the south) are the biggest islands in the Philippines. The Philippines has official local government called local government units or LGUs (Liwanag \& Wyss, 2018). It is divided into: First, regional Autonomy; second, provinces (lalawigan, probinsiya, kapuoran) and independent cities (lungsod, siyudad 
/ciudad, dakbayan, dakbanwa, lakanbalen); third, city government (bayan, balen, bungto, banwa) and the city (lungsod, siyudad / ciudad, dakbayan, dakbanwa, lakanbalen); and fourth, Barangay (barrio) (Alex B. Brillantes \& Fernandez, 2011).

\subsection{ISIS in Southeast Asia}

ISIS is a terrorist organization founded by Abu Musab al-Zarqawi in 1999 under the name Jamaat Al-Tawhid Wal-Jihad (JTWJ). Abu Musab al-Zarqawi was a student of al-Qaeda's leader Osama Bin Laden. In 2000 Zarqawi came to Osama Bin Laden as leader of Al-Qaeda to ask for help to overthrow Jordan's government. JTWJ changed to al-Qaeda in Iraq (AQI) In 2004. It had a similar target with al-Qaeda which was to control Iraq. Then in 2006 AQI changed its name to Majlis Shura Al-Mujahidin (MSM) which was still under al-Qaeda (Nainggolan, 2017).

ISIS describes a new wave of global jihadism that was previously led by the alQaeda group. ISIS was affiliated with al-Qaeda for mutual interest. At that time the ISIS was still called al-Qaeda in Iraq (AQI) with the division of Al-Qaeda's central focused on far enemies such as the United States, Israel and other global actors. Meanwhile AQI was more focused on near enemies such as Iraq and Syria which then spread to other Arab countries. In 2006, ISIS which was still called Majelis Shura al-Mujahidi (MSM), decided to leave al-Qaeda and form a new organization. After ISIS cut the tie with al-Qaeda, ISIS leader Abu Bakar al-Bagdadi declared himself as the new caliph, the highest leader of Muslims in the world. ISIS also openly challenges al-Qaeda by showing its ambition of becoming the world's main player with the ideology of Salafi jihadism. Then, ISIS began targeting the far enemy, such as the United States and Europe. However, ISIS chose not to attack the territories of the far enemy countries but attacked strategic areas of Western targets such as Baghdad, Riyadh and Damascus (Nainggolan, 2017).

\subsection{Risk Management}

Risk is the potential for something bad happening or loss of something of value. The value referred to here can be in the form of health, social status, financial wealth, goods, assets or welfare and happiness (Harris \& Jenkins, 2006). The values that can be gained or lost when taking decision to a given action or inaction. Risk can be interpreted as external factors and internal factors that can cause uncertainty in the effort to achieve the desired goals (Spikin, 2013).

Risk management is a process of identifying, analyzing, assessing, controlling, and an effort in avoiding, minimizing, or even eliminating unacceptable risks (Gebrehiwet \& Luo, 2019). In companies, risk management is a process of planning, organizing, directing, and controlling the activities of an organization to minimize the risk of company revenue (Purohit, et al., 2018). An effective risk management process will help identify which risks pose the greatest threat to the organization and provide guidance to address them (Aven, 2016).

Risk management is created in order to protect a company or organization including its employees, property, reputation etc. from a hazard that can occur at any time (Purohit, et al., 2018). Not all risks can be eliminated or avoided, therefore it is necessary to take preventative actions for the identified risks. The steps of risk management include 1) Risk identification; 2) Risk assessment; 3) Risk response; 4) Implementation; 5) Evaluate and review (Sarvari, et al., 2019). 


\subsection{Risk Analysis (Threat, Vurnerability, Impact)}

Risk analysis is the activity of analyzing risk by determining the probability and the consequences of a risk. After the risk has been identified, the next step is to carry out risk analysis and assessment (Wua, et al., 2016). Risk analysis is divided into 1) Qualitative; 2) Semiqualitative; 3) Quantitative (Matsika, et al., 2016). Qualitative risk analysis analyzes and assesses risk by comparing the parameters of the effects and opportunities by comparing the established matrix. Semiquantitative risk analysis has an almost similar method as the quantitative method (Aven, 2016). However, the difference lies in the value /score that has been determined according to the risk. Quantitative risk analysis is done by determining the value of each parameter obtained from the results of representative analysis such as statistical analysis, simulation, fault tree analysis, etc (Nazam, et al., 2015).

The parameters used in analyzing and assessing risk are threats, vulnerabilities, and impacts. A threat is something that can disrupt the activities of an organization (Liua, et al., 2012). Threats are systematic efforts to identify and evaluate existing or potential terrorist threats to jurisdiction and target assets. Due to the difficulty in assessing terrorist accurately, threat assessments can yield only general information about potential risks. This assessment considers the full spectrum of threats such as natural, criminal and major accidents, as well as terrorist activities. Threat assessment must be compiled from a comprehensive and rigorous research and analysis. Law enforcement cannot function unilaterally. Threat assessments that failed to involve the knowledge and assessment of state organization and institution, local and private organizations, with potential threats are inherently incomplete (Ganin, et al., 2017).

Vulnerability is a condition in a community or society leading to or causing the inability to deal with hazards (Ganin, et al., 2017). In principle, vulnerability analysis is used as: (1) diagnostic tool to understand the problems and factors causing vulnerability, (2) planning tool as a basis for priority determination activities and the sequence of planned activities, (3) risk measurement tool to assess risk specifically, and (4) tool for empowering and mobilizing vulnerable groups of people. Vulnerability analysis is part of a risk analysis that allows stakeholders to counter terrorism (Kaewunruen, et al., 2018).

Impact is the level or the size of influence on other activities when undesirable activities occur. Impact (consequences) Assessment is carried out to assess the consequences/ impacts of the probable occurrence of the various identified threats against the facility being reviewed. The assessment is based on criteria, including loss of life, injury, loss or damage to buildings/assets and Impact on economic and/ or socio-political well-being of the country / nation (Liua, et al., 2012).

Impact assessment in terms of number of life loss and potential number of injuries should consider the worst-case scenario of a full occupancy capacity of the facility being reviewed. The criteria of assessing loss of damage building/assets must consider the construction cost of the building/asset. The assessment on loss of primary service should be in accordance with the recovery period of re-constructing the building/asset and/or replacement of supporting equipment that determine the operability overall facility.

The risk analysis can be written with the risk formula (Liua, et al.. 2012):

Risk $=$ Threat $(\mathrm{T}) \mathrm{x}$ Vulnerability $(\mathrm{V}) \mathrm{x}$ Impact (I)

(Eq. 1) 
Liua et al (2012), describes that threat will exploit vulnerability causing an impact on the system, thus making it a risk to the organization. Therefore, if no threats, vulnerabilities and impacts are found, there is no risk (Ezell, et al., 2010).

\subsection{Analitycal Hierarchy Process (AHP)}

Analytical Hierarchy Process (AHP) is a method for solving an unstructured complex situation into several components in a hierarchical arrangement, by giving a subjective value of the relative importance of each variable, and determining which variable has the highest priority to influence the outcome of the situation (Dekrita, et al., 2018). The instrument of AHP is to have a functional hierarchy with human perception as the main input. With a hierarchy, a complex and unstructured problem is solved into groups and organized into a form of hierarchy (Mutmainah, et al., 2017).

AHP is often used more than other methods for the following reasons (Oreski, 2012):

1. Hierarchical structure as consequence of the chosen criteria, until the deepest sub criteria.

2. To consider validity up to the limit of various criteria and alternatives which is chosen by decision maker.

3. Take into account the resilience of the decision-making sensitivity analysis output.

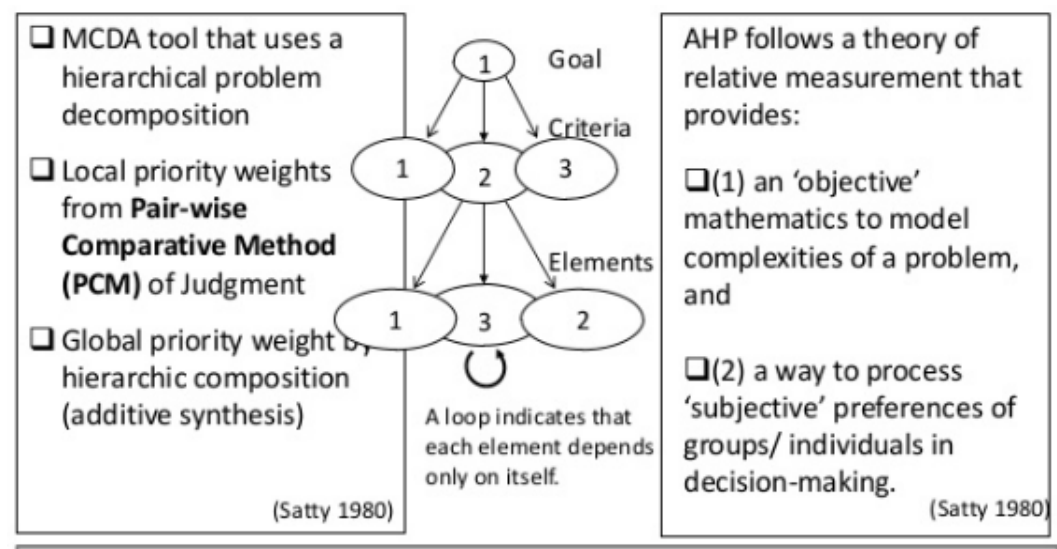

Comparison is made between two alternatives based on a decision-maker's feeling of priority due to importance, preference and likelihood of influence

Figure 1 Comparison Between MCDM dan MCDA

(Saaty, 1980)

Using a hierarchy, a complex problem can be broken down into groups which are then arranged into a hierarchical form so that the problem will appear more structured and systematic. The end of the AHP process is the priorities of the alternatives (Pérez, et al., 2017). These priorities can be used to determine the best alternative. 
Table 1 Saaty Fundamental Scale

\begin{tabular}{|c|l|}
\hline $\begin{array}{c}\text { Intensify of } \\
\text { Importance }\end{array}$ & \multicolumn{1}{c|}{ Definition } \\
\hline 1 & Two elements contribute equally to the objective (equal importance) \\
\hline 3 & $\begin{array}{l}\text { Experience and judgement slightly favour one element over another } \\
\text { (moderate more importance) }\end{array}$ \\
\hline 5 & $\begin{array}{l}\text { Experience and judgement strongly favor one element over another } \\
\text { (essential, strong more importance) }\end{array}$ \\
\hline 7 & $\begin{array}{l}\text { An element is favour very strongly over another, and its dominance is } \\
\text { demonstrated in the practice (demonstrated importance) }\end{array}$ \\
\hline 9 & $\begin{array}{l}\text { The evidence favoring one activity over another is the highest possible } \\
\text { order of affirmation (absolutely more importance) }\end{array}$ \\
\hline $2,4,6,8$ & If in doubt between two adjacent values (grey area) \\
\hline
\end{tabular}

(Saaty, 1990)

In this study, the AHP method is used to identify criteria and sub-criteria and provide weighting of those criteria. It aims at analyzing the strategic risk of Islamic State (IS) network development in Southeast Asia. The AHP method is combined with the TOPSIS method (Suryaningkusuma, et al., 2018).

\subsection{TOPSIS (Technique for Order Preference by Similarity to Ideal Solution)}

TOPSIS is one of multi-attribute decision-making methods first introduced by Yoon and Hwang in 1981. TOPSIS is based on the concept that positive ideal solution has shortest distance from positive ideal solution and farthest from negative ideal solution to determine the value of closest relative to the positive ideal optimally (Walaszczyk, 2016). The positive ideal solution is defined as the sum of all the best values that can be achieved for each attribute, while the negative ideal solution consists of all the worst values achieved for each attribute. TOPSIS considers both the distance to a positive ideal solution and the distance to a negative ideal solution by taking a closeness relative to a positive ideal solution (Basahel \& Taylan, 2016). The operation within the TOPSIS process includes: 1) creating a standard (normalized) decision matrix; 2) creating the weighted normalized decision matrix; 3) determining of positive ideal solution matrix and negative ideal solution matrix; 4) calculate the distance of each alternatives with the positive ideal solution matrix and the negative ideal solution matrix; 5) Determine the preference value for each alternative (Febriansyah, et al., 2017).

In this study, the TOPSIS method is used to calculate the value of risk analysis in several ASEAN countries in order to identify the risk analysis on the development of the Islamic State network in Southeast Asia.

\subsection{Research Subject and Object}

Research subjects are informants for the research data. Data obtained from the subject through interaction, information identification with the research subject. The interaction takes the form of interviews, focus group discussions, and surveys. In this study the informants interviewed as research subjects were the officials who were 
directly related to the threat development of the Islamic State (IS). They are classified as expert people

Table 2 Experts Panel

\begin{tabular}{|c|l|c|c|}
\hline No & \multicolumn{1}{|c|}{ Expert } & Total & Code \\
\hline 1 & $\begin{array}{l}\text { International Relations of Directorate General for Defense Strategy, } \\
\text { Ministry of Defense }\end{array}$ & 1 & E1 \\
\hline 2 & $\begin{array}{l}\text { Strategic Analysis of the Directorate-General for Defense Strategy, } \\
\text { Ministry of Defense }\end{array}$ & 1 & E2 \\
\hline 3 & $\begin{array}{l}\text { Territorial Defense of Directorate General for Defense Strategy, Ministry } \\
\text { of Defense }\end{array}$ & 1 & E3 \\
\hline 4 & $\begin{array}{l}\text { Deputy Minister for Coordinating Ministry for Political, Legal, and } \\
\text { Security Affairs of Indonesia }\end{array}$ & 1 & E4 \\
\hline 5 & Ambassador/ Defense Attaché of Thailand, Malaysia and Philippine & 3 & E5-E7 \\
\hline 6 & Ambassador/ Defense Attaché for Thailand, Malaysia and Philippine & 3 & $\begin{array}{c}\text { E8- } \\
\text { E10 }\end{array}$ \\
\hline
\end{tabular}

The object of research is a problem or issue discussed, researched and investigated in research. The object of research is something that is of concern in a study. It is the target to get answers or solutions to problems. In this research the object of research is the Islamic State (IS) network development in Southeast Asia with case studies of 4 (four) major countries, namely Indonesia, Malaysia, Thailand, the Philippines.

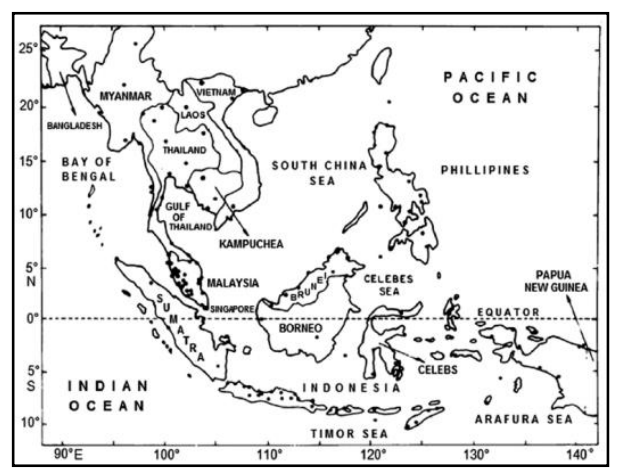

Figure 2 Southeast Asia Map

((Kripalani \& Kulkarni, 1997); (Loo, et al., 2015))

\subsection{Data Collection and Preliminary Phase}

Data collection is carried out to obtain the information needed for research objectives. Data-collecting instruments are used for data collection process. Data from each expert is recorded through the research instruments. The information was coded to facilitate the analysis process.

In this study, questionnaire, interview and observation were employed as the instruments. Previously, the instruments were constructed based on the initial criteria of each risk (Threat, Vulnerability, Impact). 
Table 3 Terrorism Risk Analysis Criteria and Sub Criteria

\begin{tabular}{|c|c|c|c|}
\hline Criteria & Sub-criteria & Code & References \\
\hline \multirow{8}{*}{$\begin{array}{c}\text { Threat } \\
\text { (T) }\end{array}$} & Existence & $\mathrm{T} 1$ & \multirow{8}{*}{$\begin{array}{l}\text { (Hosseinnia, et al., 2018) } \\
\text { (Woo, 2009) } \\
\text { (Zierhoffer, 2014) } \\
\text { (Logan \& Lloyd, 2019) } \\
\text { (Liua, et al., 2012) } \\
\text { (Ezell, et al., 2010) } \\
\text { (Ganin, et al., 2017) }\end{array}$} \\
\hline & Terror Ability & $\mathrm{T} 2$ & \\
\hline & Historic & T3 & \\
\hline & Intensity & $\mathrm{T} 4$ & \\
\hline & Type of planning activities & T5 & \\
\hline & Target strategies & T6 & \\
\hline & Total Population & $\mathrm{T} 7$ & \\
\hline & Environmental Safety & T8 & \\
\hline \multirow{5}{*}{ Vulnerability (V) } & Location & V1 & \multirow{5}{*}{\begin{tabular}{|l} 
(Kaewunruen, et al., 2018) \\
(Dumbravă \& Iacob, 2013) \\
(Hosseinnia, et al., 2018) \\
(Chien, et al., 2019) \\
(Liua, et al., 2012)
\end{tabular}} \\
\hline & Accessibility & V2 & \\
\hline & Security Adequacy & V3 & \\
\hline & Availability & V4 & \\
\hline & Vulnerability & V5 & \\
\hline \multirow{5}{*}{$\begin{array}{l}\text { Impact } \\
\text { (I) }\end{array}$} & Insignificant & I1 & \multirow{5}{*}{$\begin{array}{l}\text { (Chien, et al., 2019) } \\
\text { (Mohamed \& Elseyoufi, 2018) } \\
\text { (Hosseinnia, et al., 2018) } \\
\text { (Cioaca, et al., 2016) }\end{array}$} \\
\hline & Minor & I2 & \\
\hline & Moderate & $\mathrm{I} 3$ & \\
\hline & Major & $\mathrm{I} 4$ & \\
\hline & Catastropic & I5 & \\
\hline
\end{tabular}

\subsection{Score Column, and Colour Level}

The calculation made allows an indication of the strongest and weakest task in the terrorism risk analysis by considering accepted criteria. In such a situation, a country needs to carry out a strategic study to decide whether the risk significantly influences a country's stability.

Table 4 Value of Terrorism Risk Analysis Level.

\begin{tabular}{|c|c|c|l|l|}
\hline $\begin{array}{c}\text { AHP } \\
\text { Scale }\end{array}$ & $\begin{array}{c}\text { Likert } \\
\text { Score }\end{array}$ & $\begin{array}{c}\text { Probability } \\
\text { Value }\end{array}$ & \multicolumn{1}{|c|}{ Description } & Level \\
\hline 9 & 5 & $0,81-1,0$ & $\begin{array}{l}\text { Severe risk of terrorist attacks, increasing or } \\
\text { redirecting personnel to address critical emergency } \\
\text { needs; expand surveillance and response capability; } \\
\text { assigning emergency response personnel and pre- } \\
\text { positioning and mobilizing specially trained teams or } \\
\text { resources. }\end{array}$ & Severe \\
\hline 7 & 4 & $0,61-0,8$ & $\begin{array}{l}\text { High risk of terrorist attacks, extend monitoring } \\
\text { capability; increase security posture; Preparing to } \\
\text { execute contingency procedures; restricting threatened } \\
\text { facility access to essential personnel only. }\end{array}$ & High \\
\hline 5 & 3 & $0,41-0,6$ & $\begin{array}{l}\text { Significant risk of terrorist attack, increasing } \\
\text { surveillance of critical locations; coordinating } \\
\text { emergency plans a appropriate with nearby } \\
\text { companies. }\end{array}$ & Elevated \\
\hline 3 & 2 & $0,21-0,4$ & $\begin{array}{l}\text { General Risk of terrorist attack, heightened awareness } \\
\text { advisory notice by nearby companies or the cluster } \\
\text { security. }\end{array}$ & Guarded \\
\hline 1 & 1 & $0-0,2$ & $\begin{array}{l}\text { Low risk of terrorist attack, normal security posture } \\
\text { and conduct of business operations. }\end{array}$ & Low \\
\hline
\end{tabular}


A possibility of imminent threats or attacks on assets in a country must be immediately communicated throughout the ASEAN region to determine the appropriate security response and to enhance the protection of the target assets and make it difficult for the terrorist to endanger these assets (Table 4).

A $5 \times 5 \times 5$ matrix was developed to determine the level of warning in a country against terrorism attacks. The sub-criteria of Threat are placed on the $X$ axis while the possibility of vulnerability to attacks on the $\mathrm{Y}$ axis and impact analysis on the $\mathrm{Z}$ axis They are described in Table 9dan Figure 4.

Table 5 Value of Risk Analysis Level of Each Criteria

\begin{tabular}{|c|l|l|l|}
\hline \multirow{2}{*}{ Likert Score } & \multicolumn{3}{|c|}{ Risk Analysis Level } \\
\cline { 2 - 4 } & Threat & Vurnerabiliy & Impact \\
\hline 5 & Very High & Very High & Catastropic \\
\hline 4 & High & High & Significant \\
\hline 3 & Medium & Medium & Moderate \\
\hline 2 & Low & Low & Minor \\
\hline 1 & Very Low & Very Low & Insignificant \\
\hline
\end{tabular}

(Hosseinnia, et al., 2018); (Liua, et al., 2012); (Cioaca, et al., 2016)

Table 6 Rating of the Level Value for Each Risk Analysis Criteria

\begin{tabular}{|c|c|c|c|}
\hline \multirow{2}{*}{$\begin{array}{l}\text { Likert } \\
\text { Score }\end{array}$} & \multicolumn{3}{|c|}{ Description of Risk Analysis } \\
\hline & Threat & Vurnerabiliy & Impact \\
\hline 5 & $\begin{array}{l}\text { - Threat would have a } \\
\text { very high degree of } \\
\text { interest in the assets. } \\
\text { - Internal decision- } \\
\text { makers and/or external } \\
\text { law enforcement and } \\
\text { intelligence agencies } \\
\text { determine the threat is } \\
\text { credible. }\end{array}$ & $\begin{array}{l}\text { - the destruction of } \\
\text { more than } 10 \% \text { of } \\
\text { the considered } \\
\text { system } \\
- \text { over } 200 \text { loss of } \\
\text { life }\end{array}$ & $\begin{array}{l}\text { - Loss or damage of assets has } \\
\text { exceptionally grave consequences, } \\
\text { such as extensive loss of life, } \\
\text { widespread severe injuries, or total } \\
\text { loss of primary services, core } \\
\text { processes, and functions; property } \\
\text { damage; and a catastrophic impact on } \\
\text { economic and political well-being of } \\
\text { the nation. }\end{array}$ \\
\hline 4 & $\begin{array}{l}\text { - Threat would have a } \\
\text { high degree of interest } \\
\text { in the assets. } \\
\text { - Internal decision } \\
\text { makers and/or external } \\
\text { law enforcement and } \\
\text { intelligence agencies } \\
\text { determine the threat is } \\
\text { credible }\end{array}$ & $\begin{array}{l}\text { - The destruction of } \\
\text { more than } 25 \% \text { of a } \\
\text { subsystem - between } \\
101 \text { and } 200 \text { loss of } \\
\text { life. }\end{array}$ & $\begin{array}{l}\text { - Loss or damage of assets has grave } \\
\text { consequences, such as loss of life, } \\
\text { severe injuries, loss of primary } \\
\text { services, or major loss of core } \\
\text { processes and functions for an } \\
\text { extended period of time; and } \\
\text { functions; property damage; and a } \\
\text { major impact on economic and } \\
\text { political well-being of the nation. }\end{array}$ \\
\hline 3 & $\begin{array}{l}\text { - Threat would have } \\
\text { amoderate degree of } \\
\text { interest in the asset } \\
\text { relative to other assests. } \\
\text { - Internal decision- } \\
\text { makers and/or external } \\
\end{array}$ & $\begin{array}{l}- \text { the destruction of } \\
\text { less than } 25 \% \text { of a } \\
\text { subsystem - between } \\
51 \text { and } 100 \text { loss of } \\
\text { life }\end{array}$ & $\begin{array}{l}\text { - Loss or damage of assets have } \\
\text { moderate to serious consequences, } \\
\text { such as injuries or impairment of core } \\
\text { functions and processes; and } \\
\text { functions; property damage; and a } \\
\text { moderate impact on economic and }\end{array}$ \\
\hline
\end{tabular}




\begin{tabular}{|c|l|l|l|}
\hline & $\begin{array}{l}\text { law enforcement and } \\
\text { intelligence agencies } \\
\text { determine the threat is } \\
\text { known, but is not } \\
\text { verified. }\end{array}$ & political well-being of the nation. \\
\hline 2 & $\begin{array}{l}\text { Threat would have } \\
\text { some degree of interest } \\
\text { in the assets. } \\
- \text { Internal decision- } \\
\text { makers and/or external } \\
\text { law enforcement and } \\
\text { intelligence agencies } \\
\text { determine the threat } \\
\text { exists, but is not likely. }\end{array}$ & $\begin{array}{l}\text { of a critical } \\
\text { component from one } \\
\text { subsystem - between } \\
11 \text { and } 50 \text { loss of life }\end{array}$ & $\begin{array}{l}\text { total destruction } \\
\text { and processes for a short period of } \\
\text { time; and functions; property damage; } \\
\text { and a minor impact on economic and } \\
\text { political well-being of the nation. }\end{array}$ \\
\hline 1 & $\begin{array}{l}- \text { Threat would have } \\
\text { little to no level of } \\
\text { interest in the assets } \\
- \text { Internal decision- } \\
\text { makers and/or external } \\
\text { law enforcement and } \\
\text { intelligence agencies } \\
\text { determine the threat is } \\
\text { nonexistent or } \\
\text { extremely unlikely. }\end{array}$ & $\begin{array}{l}\text { Losequences or impact, such } \\
\text { destruction of a } \\
\text { critical component } \\
\text { from one subsystem } \\
- \text { between } 0 \text { and } 10 \\
\text { loss of life }\end{array}$ & $\begin{array}{l}\text { the partial } \\
\text { and functions; property damage; and } \\
\text { an insignificant impact on economic } \\
\text { and political well-being of the nation. }\end{array}$ \\
\hline
\end{tabular}

((Hosseinnia, et al., 2018); (Liua, et al., 2012); (Cioaca, et al., 2016))

\subsection{Research Objective and Procedure}

The objective of this research is first to identify the risks that are likely to occur and to give weight to the risk criteria and sub criteria identified. Second, it analyses the risk calculation for each criterion (threat, vulnerability impact). Third, this study provides a risk assessment analysis by multiplying the results of the analysis of risk criteria to provide the final level of risk in each country object of research on the spread of the Islamic State (IS) network. Fourth, it provides a description of the color level in the relevant country from the results of the risk analysis as part of the mapping.

Research objectives and procedures are described in formula

\section{Weighting the criteria.}

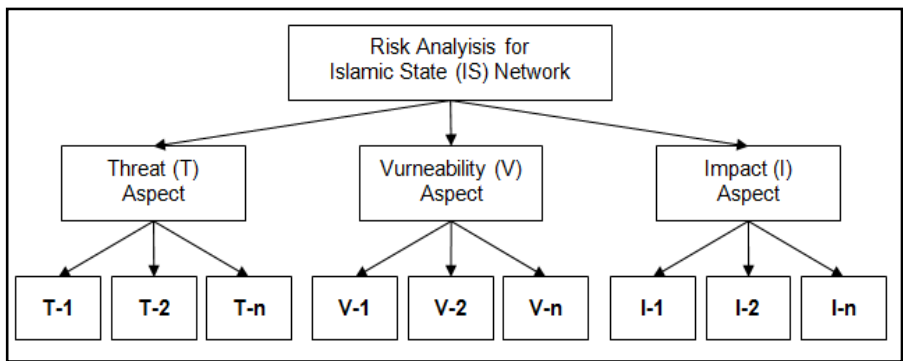

Figure 3 Risk Analysis Break-Down Structure for Islamic State (IS). (Yang, 2019) 
- $\quad$ Make a Pair Comparison Matrix (Wang \& Duan, 2019).

$$
\begin{gathered}
A=a_{i m}=\left[\begin{array}{cccc}
1 & a_{12} & \ldots & a_{1 n} \\
\frac{1}{a_{12}} & 1 & \ldots & a_{2 n} \\
\ldots & \ldots & \ldots & \ldots \\
\frac{1}{a_{1 n}} & \frac{1}{a_{2 n}} & \ldots & 1
\end{array}\right] \\
\mathrm{i}, \mathrm{m}=1,2, \ldots \ldots, \mathrm{n}=\text { index of related criteria. }
\end{gathered}
$$

- Make a Criteria Value Matrix.

- Make an Addition Matrix for Each Line.

- Calculation of Consistency Index (CI) and Consistency Ratio (CR).

$$
\begin{aligned}
& \mathrm{CI}=\frac{\lambda m a k s-n}{n} ; \\
& \mathrm{CR}=\frac{\mathrm{CI}}{\mathrm{RI}}
\end{aligned}
$$

$\mathrm{N}=$ Number of Elements,

$\mathrm{RI}=$ Random Consistency Index.

If the $\mathrm{CR}$ ratio $\leq 0.1$ (i.e. $10 \%$ ), the matrix is said to be consistent and the decision $\mathrm{W}$ is accepted. Conversely, CR more than that implies too many contradictions in the matrix. Anticipation for the final situation is to review the matrix, then revise the weights loaded by the vector.

Table 7 Random Consistency Index Values

\begin{tabular}{|c|c|c|c|c|c|}
\hline $\mathbf{n}$ & $\mathbf{R I}$ & $\mathbf{n}$ & $\mathbf{R I}$ & $\mathbf{n}$ & $\mathbf{R I}$ \\
\hline 1 & 0.00 & 6 & 1.24 & 11 & 1.51 \\
\hline 2 & 0.00 & 7 & 1.32 & 12 & 1.53 \\
\hline 3 & 0.58 & 8 & 1.41 & 13 & 1.56 \\
\hline 4 & 0.9 & 9 & 1.45 & 14 & 1.57 \\
\hline 5 & 1.12 & 10 & 1.49 & 15 & 1.59 \\
\hline
\end{tabular}

(Saaty, 1990)

2. Threat, Vulnerability, and Impact Assessments.

Table 8 Assessment of Each Criteria and Alternative

\begin{tabular}{|c|c|c|c|c|c|}
\hline Criteria & C1 & C2 & C3 & ... & C-n \\
\hline Weight & & & & & \\
\hline alternative & C1 & C2 & C3 & $\ldots$ & C-n \\
\hline & & & & & \\
\hline & & & & & \\
\hline
\end{tabular}


The Likert scale is first modified into an interval scale using Microsoft Excel to analyze the questionnaire results. Then the weights for each criterion and alternative were calculated using geometric averages. These geometric mean values are considered as the result of group assessments of the values given by 10 experts.

- Creating a matrix of terrorism risk analysis decision making (Gebrehiwet \& Luo, 2019).

- Normalizing the decision matrix (Walaszczyk, 2016) (Nazam, et al., 2015).

$$
\begin{aligned}
& X=\left[\begin{array}{cccc}
X_{11} & X_{12} & \ldots & X_{1 n} \\
X_{21} & X_{22} & \ldots & X_{2 n} \\
\ldots & \ldots & \ldots & \ldots \\
X_{m 1} & X_{m 2} & \ldots & X_{m n}
\end{array}\right] \\
& r_{i j}=\frac{X_{i j}}{\sqrt{\sum_{k=1}^{m} X_{k j}^{2}}}
\end{aligned}
$$

- Multiplying the risk matrix with the weight of each AHP criterion.

$$
\begin{gathered}
y_{i j}=w_{j} x r_{i j} \quad \text { Where } \mathrm{i}=1,2,3, . . \mathrm{m} \\
\mathrm{J}=1,2,3, \ldots \mathrm{n} \\
\mathrm{Y}=\left[\begin{array}{lllll}
w_{1} & w_{2} & \ldots & w_{m}
\end{array}\right]\left[\begin{array}{cccc}
r_{11} & r_{12} & \ldots & r_{1 n} \\
r_{21} & r_{22} & \ldots & r_{2 n} \\
\ldots & \ldots & \ldots & \ldots \\
r & r & & r
\end{array}\right]=
\end{gathered}
$$

- Determining a positive ideal solution matrix and a negative ideal solution matrix (Nazam, et al., 2015).

$$
A^{+}=\left(y_{1}^{+}, y_{2}^{+}, \ldots ., y_{n}^{+}\right) \quad \text { dan } A^{-}=\left(y_{1}^{-}, y_{2}^{-}, \ldots ., y_{n}^{-}\right)
$$

The positive ideal solution $\mathrm{A}^{+}$and the ideal solution $\mathrm{A}^{-}$can be determined based on normalized weight (yij). The normalized weight decision matrix can be calculated by multiplying the weights of the internal service quality dimension criteria with the normalized matrix. The positive ideal solution $\mathrm{A}^{+}$and the negative ideal solution $\mathrm{A}^{-}$ can be determined based on the normalized weight (yij). After obtaining the value of a positive ideal solution $\left(\mathrm{A}^{+}\right)$, then the value of the negative ideal solution $\left(\mathrm{A}^{-}\right)$is also calculated.

- Determining the distance of each alternative (Rokhsari \& Sadeghi-Niaraki, 2015).

$$
D_{i}^{+}=\sqrt{\sum_{j=i}^{n}\left(y_{i j}-y_{j}^{+}\right)^{2}} \& D_{i}^{-}=\sqrt{\sum_{j=i}^{n}\left(y_{i j}-y_{j}^{-}\right)^{2}}
$$


- Calculating the value of risk preferences of each alternative in accordance with the results of decision makers (Nazam, et al., 2015).

$$
V_{i}=\frac{D_{i}^{-}}{D_{i}^{-}+D_{i}^{+}}
$$

The preference value for each alternative (Vi) can be calculated based on the proximity of each alternative to the ideal solution.

3. Risk Determination of the Islamic State (IS) Network Development.

Table 9 Risk Analysis Results of Islamic State (IS) Network Development

\begin{tabular}{|l|c|c|c|c|c|c|}
\hline Country & $\begin{array}{c}\text { Score } \\
(\mathbf{T})\end{array}$ & $\begin{array}{c}\text { Score } \\
(\mathbf{V})\end{array}$ & $\begin{array}{c}\text { Score } \\
(\mathbf{I})\end{array}$ & $\begin{array}{l}\text { Risk Score } \\
(\mathbf{T} \text { x V x I })\end{array}$ & Alert Level & Colour \\
\hline & & & & & & \\
\hline & & & & & & \\
\hline
\end{tabular}

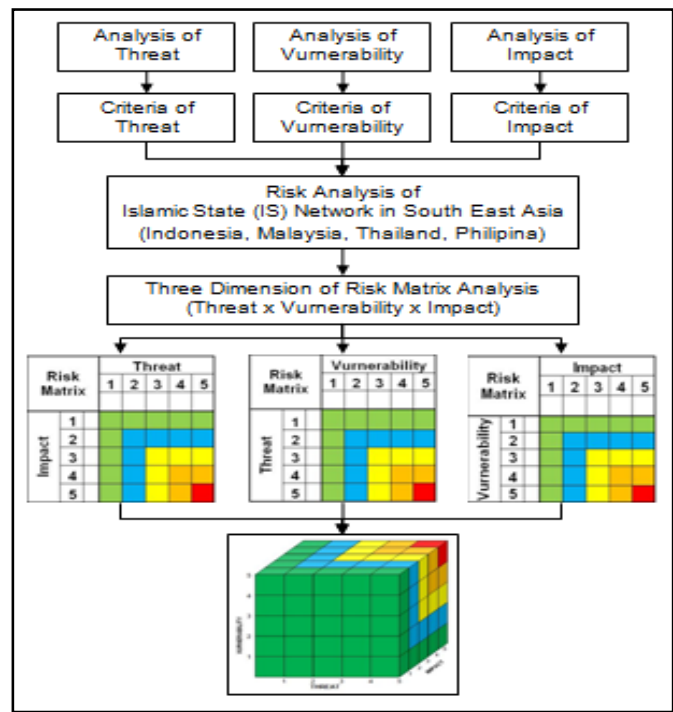

Figure 4 3D Matrix of Terrorism Risk Analysis ((Chien, et al., 2019); (Cioaca, et al., 2016)).

\section{Result}

\subsection{Analysis of Criteria Identification and Criteria Weight}

The identification of criteria in the risk analysis of Islamic State (IS) network development includes input in the form of previous studies supported by expert opinions for alternative data and processes including the stages of the AHP and the TOPSIS method, and output in the form of risk value evaluation of IS network 
development in southeast Asia. In this study the determination of criteria weights was carried out using the Analytic Hierarchy Process (AHP) method, whereas for the analysis of risk values using the TOPSIS method.

The first step in AHP is to compile a hierarchy by arranging objectives, criteria, and alternatives. Arrangement of criteria and sub-criteria for IS network development risk analysis from the opinion of experts.

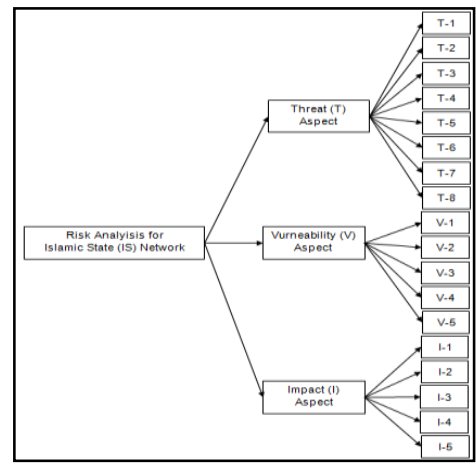

Figure 5 Hierarchical Risk Breakdown Structure on Terrorism Network Risk Analysis

Finding the influential factors or criteria was conducted to determine the risk analysis of IS network development into the structure. Therefore, building a hierarchical structure serves to build a causal relationship between risk factors. Risk analysis of the Islamic State (IS) network development has 3 (three) main criteria: vulnerabilities and impacts. Threat Criteria has 8 (eight) sub criteria; vulnerability and impact criteria each has 5 (five) sub criteria. The whole factors of the hierarchy are shown in Figure 5.

The determination of the criteria weights on the criteria and sub-criteria is done by filling in a pairwise comparison matrix and comparing the priorities of each criterion based on Table 10-Table 17. The decision makers in consist of 10 expert panels. Through a panel discussion, detailed sub-criteria under three main criteria for risk analysis (Threat, Vulnerability, Impact) were identified.

There are three levels in the hierarchical decision structure. The overall objective of the decision-making process called "Providing risk analysis to the IS network development in Southeast Asia" is at the first hierarchical level. The main criteria are at the second level, sub-criteria at the third level (Figure $\mathrm{x}$ ). In this phase, the decision makers were asked to make pairwise comparisons of the three main criteria and 18 sub criteria using linguistic variables in Table. The CR values of all matrices were less than 0.1 showing that the matrix was consistent.

Table 10 Pairwise comparisons on Main Criteria

\begin{tabular}{|l|c|c|c|}
\hline \multicolumn{1}{|c|}{ CRITERIA } & Threat (T) & Vunerability (V) & Impact (I) \\
\hline Threat (T) & 1 & 2 & 1 \\
\hline Vunerability (V) & $1 / 2$ & 1 & 1 \\
\hline Impact (I) & 1 & 1 & 1 \\
\hline
\end{tabular}


Table 11 The Main Criteria Weight

CRITERIA Threat (T) Vunerability (V) Impact (I) weight

\begin{tabular}{|lccll|}
\hline Threat (T) & 1 & 2 & 1 & 0,411 \\
Vunerability (V) & $1 / 2$ & 1 & 1 & 0,261 \\
Impact (I) & 1 & 1 & 1 & 0,328 \\
\hline CR $=$ & 0,024 & & & 1,000 \\
\hline
\end{tabular}

Table 12 Pairwise Comparison of Threat (T) Sub Criteria

\begin{tabular}{|ccccccccc|}
\hline SUB CRITERIA & T1 & T2 & T3 & T4 & T5 & T6 & T7 & T8 \\
\hline T1 & 1 & 1 & 2 & 1 & 2 & 2 & 2 & 2 \\
T2 & 1 & 1 & $1 / 2$ & $1 / 2$ & $1 / 2$ & 1 & $1 / 2$ & $1 / 3$ \\
T3 & $1 / 2$ & 2 & 1 & $1 / 2$ & $1 / 2$ & $1 / 3$ & 2 & 2 \\
T4 & 1 & 2 & 2 & 1 & 2 & 2 & 2 & 1 \\
T5 & $1 / 2$ & 2 & 2 & $1 / 2$ & 1 & $1 / 2$ & $1 / 3$ & $1 / 2$ \\
T6 & $1 / 2$ & 1 & 3 & $1 / 2$ & 2 & 1 & 2 & 2 \\
T7 & $1 / 2$ & 2 & $1 / 2$ & $1 / 2$ & 3 & $1 / 2$ & 1 & $1 / 2$ \\
\hline T8 & $1 / 2$ & 3 & $1 / 2$ & 1 & 2 & $1 / 2$ & 2 & 1 \\
\hline
\end{tabular}

Table 13 Threat (T) Sub-weighting Result

\begin{tabular}{|c|cccccccc|c|}
\hline SUB CRITERIA & T1 & T2 & T3 & T4 & T5 & T6 & T7 & T8 & Weight \\
\hline T1 & 1 & 1 & 2 & 1 & 2 & 2 & 2 & 2 & 0,175 \\
T2 & 1 & 1 & $1 / 2$ & $1 / 2$ & $1 / 2$ & 1 & $1 / 2$ & $1 / 3$ & 0,079 \\
T3 & $1 / 2$ & 2 & 1 & $1 / 2$ & $1 / 2$ & $1 / 3$ & 2 & 2 & 0,109 \\
T4 & 1 & 2 & 2 & 1 & 2 & 2 & 2 & 1 & 0,171 \\
T5 & $1 / 2$ & 2 & 2 & $1 / 2$ & 1 & $1 / 2$ & $1 / 3$ & $1 / 2$ & 0,090 \\
T6 & $1 / 2$ & 1 & 3 & $1 / 2$ & 2 & 1 & 2 & 2 & 0,147 \\
T7 & $1 / 2$ & 2 & $1 / 2$ & $1 / 2$ & 3 & $1 / 2$ & 1 & $1 / 2$ & 0,100 \\
T8 & $1 / 2$ & 3 & $1 / 2$ & 1 & 2 & $1 / 2$ & 2 & 1 & 0,128 \\
\hline CR $=$ & 0,001 & & & & & & & \\
\end{tabular}

Table 14 Pairwise Comparison of Vulnerability (V) Criteria

\begin{tabular}{|c|ccccc|}
\hline SUB CRITERIA & V1 & V2 & V3 & V4 & V5 \\
\hline V1 & 1 & 2 & $1 / 2$ & 2 & 1 \\
V2 & $1 / 2$ & 1 & 2 & 1 & 2 \\
V3 & $1 / 2$ & 1 & 1 & $1 / 2$ & $1 / 2$ \\
V4 & $1 / 2$ & 1 & 2 & 1 & $1 / 2$ \\
V5 & 1 & $1 / 2$ & 2 & 2 & 1 \\
\hline
\end{tabular}


Table 15 Vulnerability (V) Sub-Criterion Weighting Value

\begin{tabular}{|c|ccccc|c|}
\hline SUB CRITERIA & V1 & V2 & V3 & V4 & V5 & weight \\
\hline V1 & 1 & 2 & $1 / 2$ & 2 & 1 & 0,245 \\
V2 & $1 / 2$ & 1 & 2 & 1 & 2 & 0,229 \\
V3 & $1 / 2$ & 1 & 1 & $1 / 2$ & $1 / 2$ & 0,127 \\
V4 & $1 / 2$ & 1 & 2 & 1 & $1 / 2$ & 0,169 \\
V5 & 1 & $1 / 2$ & 2 & 2 & 1 & 0,230 \\
\hline CR= & 0,070 & & & & 1,000 \\
\hline
\end{tabular}

Table 16 Pairwise Comparison of Impact (I) Sub Criteria

\begin{tabular}{|c|ccccc|}
\hline SUB CRITERIA & I1 & I2 & I3 & I4 & I5 \\
\hline I1 & 1 & $1 / 2$ & $1 / 3$ & $1 / 2$ & $1 / 2$ \\
I2 & 2 & 1 & $1 / 2$ & $1 / 2$ & $1 / 2$ \\
I3 & 2 & 2 & 1 & 2 & 2 \\
I4 & 2 & 2 & $1 / 2$ & 1 & 2 \\
I5 & 2 & 2 & $1 / 2$ & $1 / 2$ & 1 \\
\hline
\end{tabular}

Table 17 Impact (I) sub-criterion Weighting

\begin{tabular}{|c|ccccc|c|}
\hline SUB CRITERIA & I1 & I2 & I3 & I4 & I5 & weight \\
\hline I1 & 1 & $1 / 2$ & $1 / 3$ & $1 / 2$ & $1 / 2$ & 0,098 \\
I2 & 2 & 1 & $1 / 2$ & $1 / 2$ & $1 / 2$ & 0,145 \\
I3 & 2 & 2 & 1 & 2 & 2 & 0,324 \\
I4 & 2 & 2 & $1 / 2$ & 1 & 2 & 0,244 \\
I5 & 2 & 2 & $1 / 2$ & $1 / 2$ & 1 & 0,189 \\
\hline CR= & 0,021 & & & & & 1,000 \\
\hline
\end{tabular}

Table 18 Analysis Weights Criteria and Sub Criteria Value

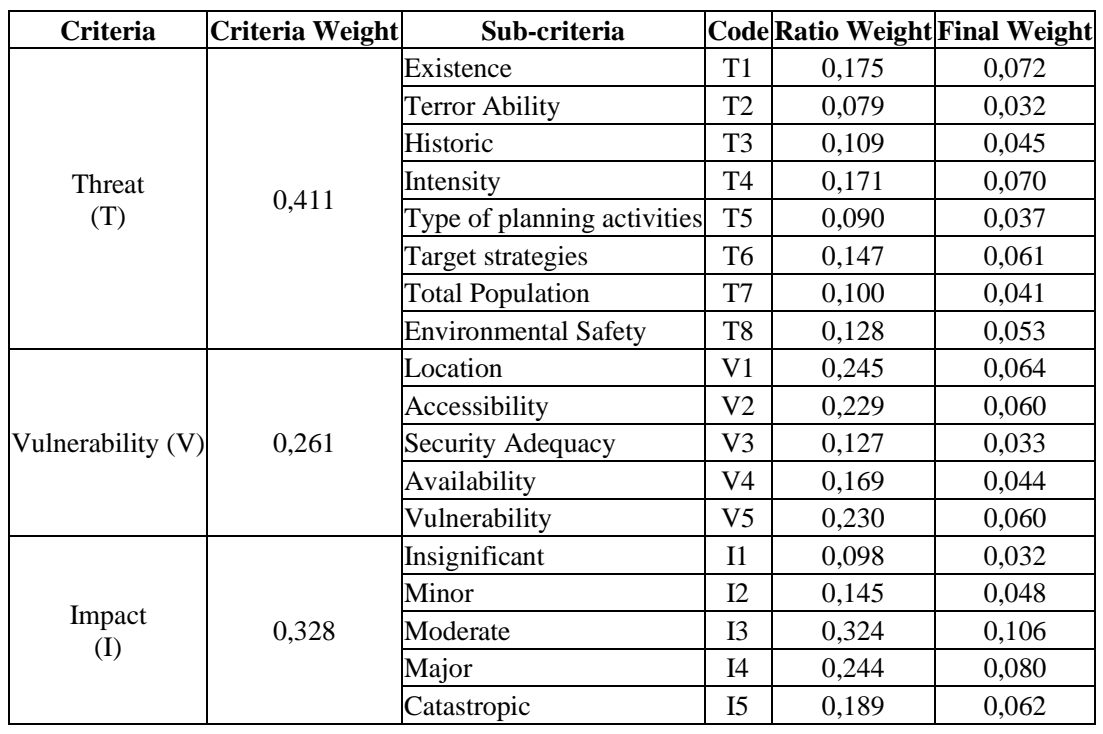




\subsection{Threat, Vulnerability and Impact Assessments}

After each criterion weight is obtained, the next process is to carry out a risk analysis of the IS network development using the Technique for Order Preference by Similarity to Ideal Solution method. To determine the risk value, TOPSIS method was employed to determine the weights for each criterion and alternative using geometric averages. These geometric mean values are considered as the result of group assessments of the values given by 10 expert panels.

Table 19 Risk Analysis of Weighted Normalized Matrix for Threat (T) Sub-Criterion

\begin{tabular}{|l|c|c|c|c|c|c|c|c|}
\hline THREAT (T) & T1 & T2 & T3 & T4 & T5 & T6 & T7 & T8 \\
\hline Weight & 0,072 & 0,032 & 0,045 & 0,070 & 0,037 & 0,061 & 0,041 & 0,053 \\
\hline Alternative & T1 & T2 & T3 & T4 & T5 & T6 & T7 & T8 \\
\hline Indonesia & 3 & 3 & 4 & 2 & 2 & 3 & 3 & 3 \\
\hline Malaysia & 3 & 2 & 3 & 2 & 2 & 2 & 3 & 2 \\
\hline Thailand & 3 & 3 & 4 & 2 & 2 & 3 & 4 & 4 \\
\hline Philippines & 4 & 3 & 4 & 3 & 3 & 3 & 4 & 3 \\
\hline
\end{tabular}

Table 20 Risk Analysis for Threat (T) Sub-Criteria

\begin{tabular}{|l|c|c|}
\hline Country & Threat (T) Analysis Result & Description \\
\hline Indonesia & 0,758 & High \\
\hline Malaysia & 0,669 & High \\
\hline Thailand & 0,790 & High \\
\hline Philippines & 0,912 & Very High \\
\hline
\end{tabular}

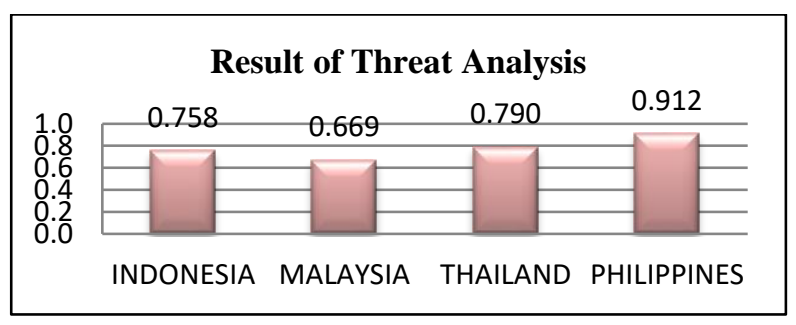

Figure 6 Threat (T) Sub-Criteria Analysis

Table 21 Risk Analysis of Weighted Normalized Matrix for Vulnerability (V) Sub-Criteria

\begin{tabular}{|l|c|c|c|c|c|}
\hline Vurnerability (V) & V1 & V2 & V3 & V4 & V5 \\
\hline Weight & 0,064 & 0,060 & 0,033 & 0,044 & 0,060 \\
\hline Alternative & V1 & V2 & V3 & V4 & V5 \\
\hline Indonesia & 3 & 3 & 3 & 3 & 4 \\
\hline Malaysia & 3 & 4 & 3 & 3 & 3 \\
\hline Thailand & 3 & 4 & 3 & 3 & 3 \\
\hline Philippines & 3 & 3 & 4 & 3 & 4 \\
\hline
\end{tabular}


Table 20 dan Figure 6 depict that Indonesia has a threat risk value of 0.758 ; Malaysia has a risk value of threats of 0.669 ; and Thailand has a threat risk value of 0.790. These three countries are at High category risk level. The Philippines has a threat risk value of 0.912 which is categorized as Very. It has the highest threat risk among the other Southeast Asian countries studied.

Table 22 Risk Analysis for Vulnerability (V) Sub-Criteria

\begin{tabular}{|c|c|c|}
\hline Country & Vulnerability (V) Analysis Result & Description \\
\hline Indonesia & 0,463 & Medium \\
\hline Malaysia & 0,461 & Medium \\
\hline Thailand & 0,461 & Medium \\
\hline Philippines & 0,539 & Medium \\
\hline
\end{tabular}

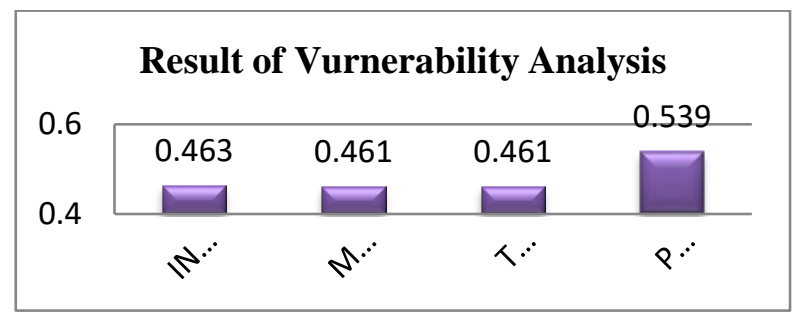

Figure 7 Vulnerability (V) Sub-criteria Analysis

The risk analysis the vulnerability criteria in Table 22 dan Figure 7 shows that Indonesia has a vulnerability risk value of 0.463 ; Malaysia has a risk value of vulnerability of 0.461 ; Thailand has a vulnerability risk value of 0.461 ; and the Philippines has a risk value of Vulnerability of 0.539 . The Philippines has the highest vulnerability risk value among other Southeast Asian countries studied. However, all four countries have a medium category.

Table 23 Risk Analysis of Weighted Normalized Matrix for Impact (I) Sub-Criteria.

\begin{tabular}{|l|c|c|c|c|c|}
\hline IMPACT (I) & I1 & I2 & I3 & I4 & I5 \\
\hline Weight & 0,032 & 0,048 & 0,106 & 0,080 & 0,080 \\
\hline Alternative & I1 & I2 & I3 & I4 & I5 \\
\hline Indonesia & 2 & 2 & 3 & 2 & 2 \\
\hline Malaysia & 2 & 3 & 2 & 2 & 2 \\
\hline Thailand & 2 & 2 & 3 & 2 & 2 \\
\hline Philippines & 2 & 2 & 3 & 3 & 2 \\
\hline
\end{tabular}

Table 24 Risk Analysis for Impact (I)Sub-Criteria

\begin{tabular}{|l|c|c|}
\hline Country & Impact (I) Analysis Result & Description \\
\hline Indonesia & 0,484 & Moderate \\
\hline Malaysia & 0,287 & Minor \\
\hline Thailand & 0,484 & Moderate \\
\hline Philippines & 0,713 & Significant \\
\hline
\end{tabular}




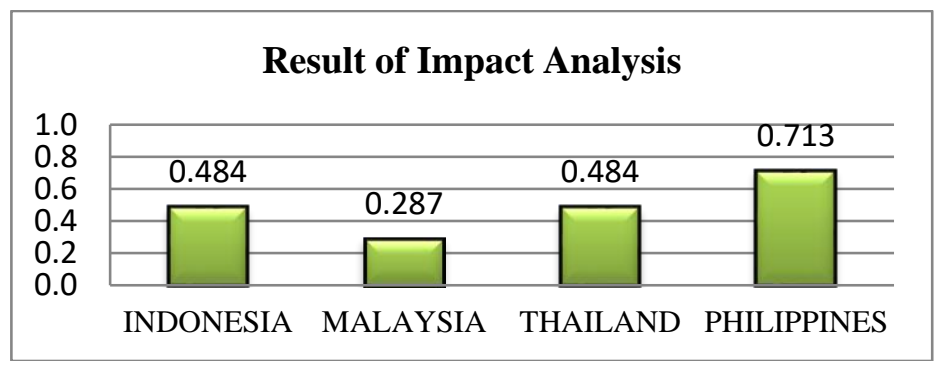

Figure 8 Impact (I) Sub-criteria Analysis

Based on the results of the risk analysis of the Impact criteria in Table 24 dan Figure 8 , it is revealed that Indonesia has an impact risk value of 0.484 with the moderate category; Malaysia has an impact risk value of 0.287 with a minor category; Thailand has an impact risk value of 0.484 with the moderate category; and the Philippines has a significant impact risk value of 0.713. The Philippines has the highest Impact risk value among other Southeast Asian countries examined.

\subsection{Risk Determination}

\section{Discussion}

Table 25 Risk Analysis of Islamic State (IS) Network in Southeast Asia

\begin{tabular}{|l|c|c|c|c|c|}
\hline Country & $\begin{array}{c}\text { Threat } \\
\text { Score }\end{array}$ & $\begin{array}{c}\text { Vurnerability } \\
\text { Score }\end{array}$ & $\begin{array}{c}\text { Impact } \\
\text { Score }\end{array}$ & $\begin{array}{c}\text { Risk Score } \\
\text { (T X V X I) }\end{array}$ & $\begin{array}{c}\text { Colour } \\
\text { Level }\end{array}$ \\
\hline Indonesia & 0,758 & 0,463 & 0,484 & 0,170 & Low \\
\hline Malaysia & 0,669 & 0,461 & 0,287 & 0,088 & Low \\
\hline Thailand & 0,790 & 0,461 & 0,484 & 0,176 & Low \\
\hline Philippines & 0,912 & 0,539 & 0,713 & 0,351 & Guarded \\
\hline
\end{tabular}

After collecting inputs and choosing risk analysis techniques, analysis results explain that several conditions stand out and at each stage of construction. The risks to be encountered in terms of national security in each country will certainly vary according to the existing geopolitical conditions.

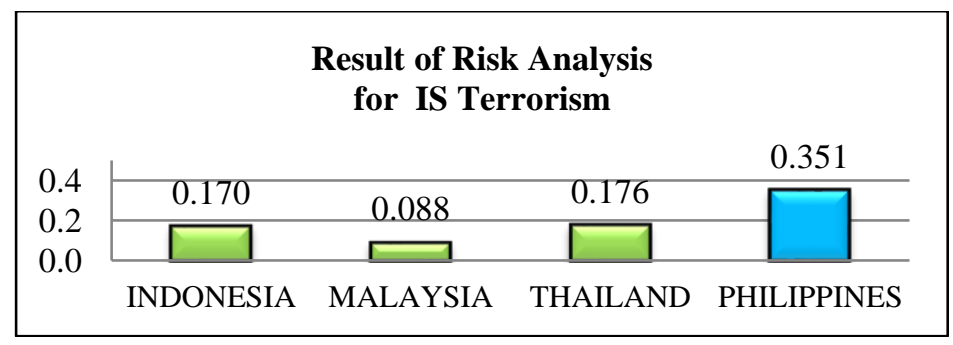

Figure 9 Risk Analysis of Islamic State (IS) Network in Southeast Asia 
At Table 25 dan Figure delineate that the risk value comes from the multiplication between the value of the threat, vulnerability and impact. Based on the results of risk calculations, the Philippines has the highest risk factor value with a value of 0.351 at level 2. While the other three countries have a risk factor at level 1 . Indonesia has a value of 0.170 Malaysia has value of 0.088 ; and Thailand with a value of 0.176 .

The three countries at level 1 are countries having no base of developing military wing. In Indonesia there are several Islamic-based organizations that have direct or indirect affiliations with the Islamic State (IS). The threat of IS can be conditioned as an unreal threat. However, the existence of some terrors that occurred in Surabaya in 2018 had provided firm evidence that IS was still free to carry out activities due to social, economic and religious factors of Indonesia.

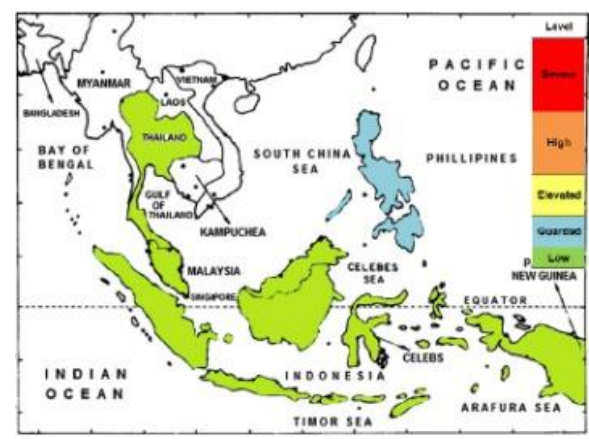

Figure 10 Risk Analysis of the Islamic State (IS) Network in Southeast Asia Mapping

In Thailand, the Muslim is a minority. Muslim community in Thailand is largely comes from Malay race. However, there were several protests due to the prohibition of using Malay, teaching Islam in schools etc. These conditions discriminated Muslim people, and in the end, there was a violence and murder which is also an act of Terrorism. The next resistance movement emerged in the $1960 \mathrm{~s}$ led by Tengku Abdul Jalil who founded the National Liberation Front of Patani (NLFP). This movement actually triggered the emergence of other resistance organizations such as National Revolutionary Front and Patani United Liberation Organization (PULO) demanded Southern Thailand to ve divided into four regions namely Pattani, Yala, Songkhla, and Narathiwat. However, Thailand is still at a stable level 1 from risk analysis of terorism networks in Southeast Asia.

In Malaysia, the development of the terror network was initiated by the formation of Mujahidin to help Afghan mujahidin's fight against the Soviet Army. Malaysia's current terror network that stands out is IS network, which was initially intruded by Jemaah Islamiyah and Mujahidin. Currently, it is intruded by separatists of Aceh and Sri Lanka. This terror network fled through Southern Thailand, which then entered Malaysia to declare its goal to Malaysia in establishing an Islamic state in Southeast Asia in general and the Islamic state in Sri Lanka in particular. However, Malaysia is still at level 1 based on the risk analysis of terrorism networks in Southeast Asia.

The Philippines has the highest risk at level 2. There are hardline fighters with a strong ideology-based and paramilitary character called the Moro National Liberation Front or known as MNLF fighters. After the defeat of ISIS in 2015, ISIS 
leader Abubakar Al-Bagdadi indoctrinated his followers to return to their respective countries to establish an Islamic State in their country. On of the member of ISIS in Philippines, the leader of ASG namely Isnilon Hapilon is the leader of the ISIS in Southeast Asia. The Returnees were involved in kidnappings and hostages through the active ASG igniting Moro resistance at Marawi on May 23, 2017. Duterte decided that the Philippine government imposed martial law until July 26, 2017 which then extended to December 26, 2017. Peace and rebellion continued to roll in the Philippines. It is difficult to resolve because the relationship of Islamic Ideology also originates from neighbouring countries such as Southern Thailand, Malaysia, and Indonesia. However, the existence of the Islamic State (IS) network in the Philippines did not cause damage as happened in Syria.

\section{Conclusion}

The Islamic State (IS) terrorism network in southeast Asia is inseparable from the spread of power from Islamic state groups in Iraq and Syria. The presence of combatants from various countries had an impact on the risk of the development of the Islamic State, especially those who come from Southeast Asia.

According to the risk analysis result on development of the Islamic State (IS) network, Indonesia has a threat risk value of 0.758 with the category of High; Malaysia has a risk value of threat of 0.669 with the High category; Thailand has a threat risk value of 0.790 with the High category; and the Philippines has a threat risk value of 0.912 with the category of Very High. Based on the results of the risk analysis of the criteria of Vulnerability, it is found that Indonesia has a vulnerability risk value of 0.463 ; Malaysia has a risk value of 0.461 ; Thailand has a risk value of 0.461 ; and the Philippines has a risk value of 0.539. All countries mentioned are categorized in the Medium category. While the risk analysis of the criteria of Impact revealed that Indonesia has an Impact risk value of 0.484 with the moderate category; Malaysia has an Impact risk value of 0.287 with a minor category; Thailand has an Impact risk value of 0.484 with the moderate category; and the Philippines has a significant risk value of 0.713 .

Finally, the risk analysis of the development of Islamic State in Southeast Asia resulted three countries were categorized in the category of Low: Indonesia, Malaysia and Thailand. Indonesia has the value of risk factor of 0.170; Malaysia has the value of risk factor of 0.088 and Thailand has the value of risk factor of 0.176 . On the other hand, the Philippines has the value of risk factor of 0.351 in the category of Guarded.

\section{Future Work}

- Future studies are encouraged to implement a risk mitigation strategies of Islamic state (IS) terrorism network in Southeast Asia in an effort to support the countries' cooperation between security services on the counter terrorism field.

- Prospective studies are expected to conduct risk factor analysis toward other Southeast Asian countries in order to identify the entirety of the development of the Islamic State (IS). 


\section{Acknowledgement}

A deepest gratitude is addressed to Universitas Pertahanan Indonesia (Indonesian Defense University) for the support during the research. A profound appreciation is also expressed National Defence University of Malaysia (UPNM) for the sustainable research collaboration.

\section{References}

1. Alex B. Brillantes, J., \& Fernandez, M. T. (2011). Restoring Trust and Building Integrity in Government: Issues and Concerns in the Philippines and Area for Reform. International Public Management Review, 12(2), 55-80.

2. Aslam, M. (2009). A Critical Study of Kumpulan Militant Malaysia, Its Wider Connections in the Region and the Implications of Radical Islam for the Stability of the Southeast Asia (1st ed.). New Zealand: Victoria University of Wellington.

3. Aven, T. (2016). Risk assessment and risk management: Review of recent advances on their foundation . European Journal of Operational Research , 253, $1-13$.

4. Baker, D. M. (2014). The Effects of Terrorism on the Travel and Tourism. International Journal of Religious Tourism and Pilgrimage, 2(i), 58-68.

5. Basahel, A., \& Taylan, O. (2016). Using Fuzzy AHP And Fuzzy TOPSIS Approaches For Assessing Safety Conditions At Worksites In Construction Industry. Int. J. of Safety and Security Eng, 6(4), 728-745.

6. Beinoravičius, D., \& Vainiutè, M. (2017). The Management of Terrorism Roots as a Prerequisite for Successful Fight Againts Terrorism. Journal of Security and Sustainability Issues, 7(2), 13-22.

7. Berkell, K. (2017). Risk Reduction In Terrorism Cases: Sentencing And The Post-Conviction Environment . Journal for Deradicalization, 18(13), 276-341.

8. Bona, G. D., \& Falcone, D. (2019). AHP-TOPSIS Model to Evaluate Maintenance Strategy using RAMS and Production Parameters. International Journal of Operations and Quantitative Management, 25(3), 175-201.

9. Borum, R. (2015). Assessing Risk For Terrorism Involvement . Journal of Threat Assessment and Management, 2(2), 63-87.

10. Chien, L.-K., Wu, J.-P., \& Tseng, W.-C. (2019). The Study of Risk Assessment of Soil Liquefaction on Land Development and Utilization by GIS in Taiwan. Dalam Geographic Information Systems (hal. 1-19). Intechopen.

11. Cioaca, C., Constantinescu, C.-G., Boscoianu, M., \& Lile, R. (2016). Extreme Risk Assessment Methodology (ERAM) in Aviation System. Environmental Engineering and Management Journal, 14(6), 1399-1408.

12. Dekrita, Y. A., Yunus, R., Citta, A. B., \& Yamin, M. (2018). Integration of Balanced Scorecard and Analytical Hierarchy Process as a Tool for Determining the Priority of the Program Strategy: Case Study in Dr. Tc.Hillers Maumere Hospital. 3rd International Conference on Accounting, Management and Economics.

13. Dumbravă, V., \& Iacob, V. -S. (2013). Using Probability - Impact Matrix in Analysis and Risk Assessment Projects. Journal of Knowledge Management, Economics and Information Technology, 76-96. 
14. Ezell, B. C., Bennett, S. P., Winterfeldt, D. v., Sokolowski, J., \& Collins, A. J. (2010). Probabilistic Risk Analysis and Terrorism Risk. Risk Analysis, 30(4), 575-589.

15. Febriansyah, J., Gernowo, R., \& Kusumawardhani, A. (2017). Implementation of AHP and TOPSIS Method to Determine the Priority of Improving the Management of Government's Assets. International Journal of Innovative Research in Advanced Engineering, 4(3), 46-53.

16. Filippo, M. D. (2008). Terrorist Crimes and International Co-operation: Critical Remarks on the Definition and Inclusion of Terrorism in the Category of International Crimes. European Journal of International Law, 19(3), 533-570.

17. Fitriani, Satria, A., Nirmalasari, P. P., \& Adriana, R. (2018). The Current State of Terrorism in Indonesia: Vulnerable Groups, Networks, and Responses (2nd ed.). Jakarta: Centre for Strategic and International Studies.

18. Fitzpatrick, J. (2003). Speaking Law to Power: the War Againt Terrorism and Human Right. European Journal of International Law, 14(2), 241-264.

19. Ganin, A. A., Quach, P., Panwar, M., Collier, Z. A., Keisler, J. M., Marchese, D., \& Linkov, I. (2017). Multicriteria Decision Framework for Cybersecurity Risk Assessment and Management. Risk Analysis, 1-17.

20. Gebrehiwet, T., \& Luo, H. (2019). Risk Level Evaluation on Construction Project Lifecycle Using Fuzzy Comprehensive Evaluation and TOPSIS. Symmetry, 11(12), 1-15.

21. Harris, C. R., \& Jenkins, M. (2006). Gender Differences in Risk Assessment: Why do Women Take Fewer Risks than Men? Judgment and Decision Making, 1(1), 48-63.

22. Hatta, Z. A., \& Ali, I. (2013). Poverty Reduction Policies in Malaysia: Trends, Strategies and Challenges. sian Culture and History, 5(2), 48-56.

23. Hosseinnia, B., Khakzad, N., \& Reniers, G. (2018). An Emergency Response Decision Matrix Againts Terrorist Attack with Improvised Device in Chemical Cluster. International Journal of Safety and Security Engineering, 8(2), 187199.

24. Husin, S., Fachrurrazi, F., Rizalihadi, M., \& Mubarak, M. (2019). Implementing Fuzzy TOPSIS on Project Risk Variable Ranking. Advances in Civil Engineering, 1-10.

25. Kaewunruen, S., Alawad, H., \& Cotruta, S. (2018). A Decision Framework For Managing The Risk Of Terrorist Threats At Rail Stations Interconnected With Airports . Safety, 36(4), 1-19.

26. Koulinas, G., Demesouka, O., Marhavilas, P., Vavatsikos, A., \& Koulouriotis, D. (2019). Risk Assessment Using Fuzzy TOPSIS and PRAT for Sustainable Engineering Projects . Sustainability, 11(615), 1-15.

27. Kripalani, R., \& Kulkarni, A. (1997). Rainfall Variability Over South-East AsiaConnections with Indian Monsoon and Enso Extremes: New Perspective. International Journal of Climatology, 17, 1155-1168.

28. Leepreecha, P. (2019). Becoming Indigenous Peoples in Thailand . Journal of Southeast Asian Studies, 50(1).

29. Liua, C., Tan, C.-K., Fang, Y.-S., \& Lok, T.-S. (2012). The Security Risk Assessment Methodology. 43, hal. 600-609. International Symposium on Safety Science and Engineering in China. 
30. Liwanag, H., \& Wyss, K. (2018). What conditions enable decentralization to improve the health system? Qualitative analysis of perspectives on decision space after 25 years of devolution in the Philippines. PLoS ONE, 13(11), 1-20.

31. Logan, C., \& Lloyd, M. (2019). Violent extremism: A Comparison of Approaches to Assessing and Managing Risk. Legal and Criminological Psychology, 24, 141-161.

32. Loo, Y. Y., Billa, L., \& Singh, A. (2015). Effect of climate change on seasonal monsoon in Asia and its impact on the variability of monsoon rainfall in Southeast Asia. Geoscience Frontiers, 6, 817-823.

33. Malta, Sumardjo, Fatchiya, A., \& Susanto, D. (2018). Keberdayaan Transmigran dalam Berusahatani di Kabupaten Banyuasin dan Ogan Ilir Provinsi Sumatera Selatan. Jurnal Penyuluhan, 14(2), 257-270.

34. Matsika, E., O’Neill, C., Battista, U., Khosravi, M., Laporte, A. d., \& Munoz, E. (2016). Development Of Risk Assessment Specifications For Analysing Terrorist Attacks Vulnerability On Metro And Light Rail Systems. Transportation Research Procedia, 14, 1345 - 1354.

35. Mohamed, T. Z., \& Elseyoufi, T. S. (2018). Terrorism in the Middle East: Implications on E orism in the Middle East: Implications on Egyptian T gyptian Travel and Tourism. International Journal of Religious Tourism and Pilgrimage, 6(3), 86-106.

36. Mutmainah, Marfuah, U., \& Panudju, A. T. (2017). Employee Performance Appraisal Model Using Human Resources Scorecard And Analytical Hierarchy Process (AHP). Journal of Scienctific \& Technology Research, 6(11), 81-84.

37. Nahdohdin, M., Angelianawati, D., Yaoren, K. Y., Dhanaraj, J., Bashar, I., See, S., \& Nasir, A. A. (2019). Southeast Asia: Indonesia, Philippines, Malaysia, Myanmar, Thailand, Singapore. A Journal of the International Centre for Political Violence and Terrorism Research (ICPVTR), 11(1), 6-32.

38. Nainggolan, P. P. (2017). Kekhalifahan ISIS di Asia Tenggara, Sekedar Wacana atau Realitas ? Politica, 8(2), 205-230.

39. Nazam, M., Xu, J., Tao, Z., Ahmad, J., \& Hashim, M. (2015). A fuzzy AHPTOPSIS Framework for The Risk Assessment of Green Supply Chain Implementation In The Textile Industry. International Journal of Supply and Operations Management, 2(1), 548-568.

40. Nikkhah, M., Ghasvareh, M., \& Bahalgardi, N. F. (2019). Risk Management In Urban Tunnels Using Methods Of Game Theory And Multi-Criteria DecisionMaking. Journal of Mining and Environment, 10(3), 597-611.

41. Norouzi, A., \& Namin, H. G. (2019). A Hybrid Fuzzy TOPSIS - Best Worst Method for Risk Prioritization in Megaprojects. Civil Engineering Journal, 5(6), 1257-1272.

42. Oreski, D. (2012). Strategy development by using SWOT - AHP. TEM Journal, 1(4), 283-290.

43. Pavlićević, P. (2017). Rationality Of Terrorist Acts, Counterterrorism And Risk Analysis. Law and Politics, 15(4), 291 - 304.

44. Pérez, C. Á., Montequín, V. R., Fernández, F. O., \& Balsera, J. V. (2017). Integrating Analytic Hierarchy Process (AHP) and Balanced Scorecard (BSC) Framework for Sustainable Business in a Software Factory in the Financial Sector. Sustainability, 9, 1-16. 
45. Purohit, D. P., Siddiqui, N. A., Nandan, A., \& Yadav, B. P. (2018). Hazard Identification and Risk Assessment in Construction Industry. International Journal of Applied Engineering Research, 13(10), 7639-7667.

46. Purwendah, E. K. (2018). The Implementation of Agreement on Transboundary Haze Pollution in The Southeast Asia Region for ASEAN Member Countries. International Journal of Business, Economics and Law, 17(4), 8-14.

47. Putra, B. A., Darwis, \& Burhanuddin. (2019). ASEAN Political-Security Community: Challenges of establishing regional security in the Southeast Asia . Journal of International Studies, 12(1), 33-49.

48. Rokhsari, S., \& Sadeghi-Niaraki, A. (2015). Urban Network Risk Assessment Based on Data Fusion Concept using Fuzzy-AHP, TOPSIS and VIKOR in GIS Environment. Iranian Journal of Operations Research, 6(2), 73-86.

49. Saaty, T. L. (1980). The Analytical Hierarchy Process. New York: McGraw Hill.

50. Saaty, T. L. (1990). How to make a Decision : The Analytic Hierarchy Process. European Journal of Operation Research, 9-11.

51. Sadeh, N., \& Rezaian, S. (2017). Risk Management and Control of Dams Based on Integrating TOPSIS and RAM-D Techniques (Case Study: Paveh Rood Dam, Iran). Environmental Energy and Economic Research, 1(4), 363- 372.

52. Sarma, K. M. (2017). Risk Assessment And The Prevention Of Radicalization From Nonviolence Into Terrorism. American Psychologist, 72(3), 278-288.

53. Sarvari, H., Valipour, A., Yahya, N., Noor, N. M., Beer, M., \& Banaitiene, N. (2019). Approaches to Risk Identification in Public-Private Partnership Projects: Malaysian Private Partners' Overview. Administrative Science, 9(17), 1-18.

54. Šinka, D., Krajcar, S., \& Bajs, T. (2016). Assessing Terrorist Threats For Energy Infrastructure By Combining Historical Data And Expert Judgments. National Security and The Future, 17(1), 153-166.

55. Suharyo, O. S., Manfaat, D., \& Armono, H. D. (2017, March). Establishing the Location of Naval Base Using Fuzzy MCDM and Covering Technique Methods : A Case Study. International Journal of Quantitative Management, 23(1).

56. Spikin, I. C. (2013). Risk Management Theory: the Integrated Perspective and Its Application in the Public Sector. Estado, Gobierno, Gestión Pública, 21, 89126.

57. Suryaningkusuma, R. P., Subyantoro, A., \& Sabihaini. (2018). Combining Analytical Hierarchy Process and Simple Multi-Attribute Rating Technique for designing a Sustainable Balanced Scorecard as Strategic Performance Measurement System. International Journal of Computer Science and Network, 7(4), 279-288.

58. Susilo, A. K., Ciptomulyono, U., Putra, I. N., Ahmadi, \& Sutrisno. (2018). Maritime Strategy Development to Encounter the Threat of National Sea Security in Indonesia Territory. Journal of Defense Resources Management, 9(2), 147-169. Diambil kembali dari http://www.jodrm.eu/issues/Volume9 issue2/12\%20\%20Susilo,\%20Ciptomulyono,\%20Putra,\%20Ahmadi,\%20Sutrisno.pdf 
59. Susilo, A. K., Putra, I. N., Ahmadi, \& Suharyo, O. S. (2019). Analysis of National Maritime Security Strategy as an Effect of Regional Development using SWOT- Fuzzy Multi Criteria Decision Making (FMCDM)-Borda. nternational Journal of Operations and Quantitative Management , 25 (3).

60. Walaszczyk, L. (2016). Project Risk Assessment in Enterprises with the Use of TOPSIS Method in the 2014-2020 Perspective. Studia i Materialy, 2(21), 71-79.

61. Wang, S., Wang, G., \& Zhang, J. (2019). Data Analysis Method Of Terrorist Attacks Based On AHP-DBSCAN Method . Journal of Physics, 1168, 1-8.

62. Wang, X., \& Duan, Q. (2019). Improved AHP-TOPSIS Model for The Comprehensive Risk Evaluation of Oil And Gas Pipelines. Petroleum Science, $16,1479-1492$.

63. Woo, G. (2009). Terrorism Threat Assessment and Management. Defence Against Terrorism Review, 2(1), 101-116.

64. Wua, W., Kou, G., \& Peng, Y. (2016). Group Decision-Making Using Improved Multi-Criteria Decision Making Methods for Credit Risk Analysis. Filomat, 30(15), 4135-4150.

65. Yang, J. (2019). Risk Evaluation Of Terrorist Attacks Against Important Chemical Industries In Urban Areas. International Conference on Education, Management Science and Economics (hal. 1-4). Wuhan: Atlantic Press.

66. Zawadzki, M., Costa, A. N., Belderrain, M. C., \& Montibeller, G. (2017). Adversarial Risk Analysis in support of defensive resource allocation for counterterrorism. Gest. Prod., 24(3), 450-463.

67. Zhang, X., Jin, M., Fu, J., Hao, M., Yu, C., \& Xie, X. (2018). On The Risk Assessment Of Terrorist Attacks Coupled With Multi-Source Factors . ISPRS Int. J. Geo-Inf, 7(354), 1-19.

68. Zierhoffer, D. M. (2014). Threat Assessment: Do Lone Terrorists Differ from Other Lone Offenders? . Journal of Strategic Security, 7(3), 48-62.

\section{About Our Authors}

Amarulla Octavian, Vice Admiral Amarulla Octavian graduated from Naval Academy in 1988 and was assigned onboard destroyer and frigates until 2002. He is the associate professor and researcher on maritime security, military sociology, and naval strategy. He was a visiting professor for Naval Postgraduates School in 2016, Japan National Defense Academy in 2017, Rumania "Carol I" National Defense University in 2017 and PLA National Defense University in 2018. He holds a bachelor degree from Indonesia Naval Technology College in 2001, Master of Science degree from Université Paris 2 Panthéon-Assas in 2006 and doctorate degree on military sociology from Indonesia University in 2013.

Joni Widjayanto, Brigadier General Joni Widjayanto is the secretary of the Institute for Research and Community Service. Joni Widjayanto Graduated from the military academy in 1989, was an Army Officer from the infantry Corps. He graduated undergraduate in 1995, continued to graduate two master's programs in 2010 and 2017. Joni Widjayanto completed his doctoral studies in 2018. 
I Nengah Putra, Captain in Indonesia Navy. He is Associate Professor at the Indonesia Defense University (IDU), Master graduated from Indonesia Defense University and received his Ph.D at the Brawijaya University. He leads the research activities in the Environmental Engineering, especially in cyber-space.

A. Kukuh Susilo, Lieutenant Commander in Indonesia Navy, he is Master of Engineering, especially in reliability and operation research. He is a Researcher at Indonesia Naval Institute of Technology (STTAL). He is involved in research about system analyzes and military operation research model.

Okol Sri Suharyo, Commander in Indonesia Navy, got a Master Degree in Sea Transport Engineering (2008) and a Ph.D. (2015) at the Faculty of Marine Technology, Sepuluh Nopember Institute of Technology ITS (Indonesia). Since 2009, he has been Researcher and Lecturer at Indonesia Naval Institute of Technology (STTAL), he teaches "Military Operation Research" in the Engineering degree course. He is involved in research about system analyzes and military operation research model. 